\title{
Anna Tokarz-Kocik
}

Uniwersytet Szczeciński

e-mail: anna.tokarz@wzieu.pl

\section{INWESTYCJE RETENCYJNE W KAPITAŁ LUDZKI W HOTELARSTWIE. ASPEKTY TEORETYCZNE}

\section{RETENTION INVESTMENTS IN HUMAN CAPITAL IN THE HOTEL INDUSTRY. THEORETICAL ASPECTS}

DOI: $10.15611 / \mathrm{pn} .2017 .473 .53$

JEL Classification: J24, L20, M12

Streszczenie: Jednym z podstawowych problemów branży hotelarskiej jest wysoki poziom rotacji kadr. Problem ten po części powodowany jest szybkim wzrostem liczby obiektów hotelarskich i popytem na doświadczonych pracowników. Głównie jednak wynika z ograniczonych inwestycji retencyjnych, tj. mało konkurencyjnych warunków płacowych i zasad motywowania stosowanych przez obiekty hotelarskie. Celem artykułu jest przedstawienie znaczenia inwestycji retencyjnych, takich jak: szkolenia, odpowiednia treść pracy, programy praca-życie dla funkcjonowania przedsiębiorstwa hotelarskiego. Przedmiotem rozważań w niniejszym artykule jest inwestowanie w kapitał ludzki na poziomie mikroekonomicznym (świadomie pominięto analizę inwestowania w sferę B + R oraz w edukację w systemie szkolnym). Artykuł jest wynikiem studiów literaturowych oraz analizy dostępnych danych wtórnych, dotyczących analizowanego zagadnienia.

Słowa kluczowe: kapitał ludzki, inwestycje retencyjne, hotelarstwo.

Summary: One of the basic problems of the hotel industry is the high level of staff turnover. This problem is partly due to the rapid development of the number of hotel facilities and the demand for experienced staff. Mostly, however, it results from limited retention investments, i.e. less competitive wage conditions and motivation rules applied by hotel establishmentsThe objective of the article is to present an impact of investments such as trainings and work-life programs for the functioning of enterprises in hotel industry. The objective of the article is to present an impact of investments such as trainings and work-life programs for the functioning of enterprises in hotel industry. The focus of this article is the investing in human capital at the microeconomic level (deliberately bypassing the analysis of R\&D investment and education in the school system). The article constitutes the results of literature studies and an analysis of available secondary data on the analysed issue.

Keywords: human capital, retention retention, hospitality. 


\section{Wstęp}

Przetrwanie i rozwój przedsiębiorstwa hotelarskiego w warunkach wciąż nasilającej się konkurencji wymagają inicjatywy, współdziałania i zaangażowania wszystkich jego pracowników. Sytuacja na rynku pracy powoduje, że pracodawcy muszą nie tylko zabiegać o najlepszych specjalistów, ale również starać się ich zatrzymać $\mathrm{w}$ przedsiębiorstwie hotelarskim. Wymaga to inwestowania w składowe kapitału ludzkiego w organizacji.

Przedmiotem rozważań w niniejszym artykule jest inwestowanie w kapitał ludzki na poziomie mikroekonomicznym (świadomie pominięto analizę inwestowania $\mathrm{w}$ sferę $\mathrm{B}+\mathrm{R}$ oraz w edukację w systemie szkolnym). Celem artykułu jest przedstawienie znaczenia takich inwestycji retencyjnych, jak: szkolenia, odpowiednia treść pracy, programy praca-życie dla funkcjonowania przedsiębiorstwa hotelarskiego. Artykuł jest wynikiem studiów literaturowych oraz analizy dostępnych danych wtórnych, dotyczących analizowanego zagadnienia.

\section{Klasyfikacja inwestycji w kapitał ludzki}

Inwestowanie to jedna z podstawowych działalności człowieka w dziedzinie ekonomii [Jajuga, Jajuga 2000, s. 7]. Proces ten polega na angażowaniu kapitału w przedsięwzięcia gospodarcze mające na celu powiększenie majątku posiadaczy kapitału. W przedsiębiorstwach usługowych (w tym hotelarskich) szczególne znaczenie ma inwestowanie w składowe kapitału ludzkiego w organizacji, takie jak wiedza, umiejętności, zdolności, zdrowie, motywacja, postawy, które mają określoną wartość w sensie ekonomicznym oraz stanowią źródło przyszłych dochodów zarówno dla pracownika - właściciela kapitału ludzkiego, jak i organizacji korzystającej na określonych warunkach z tegoż kapitału [Becker 1962, s. 9-49; Król 2006, s. 97].

Inwestycje w kapitał ludzki to rodzaj inwestycji niematerialnych polegających na celowym, obarczonym ryzykiem ponoszeniu przez pewien czas (przy rezygnacji lub zmniejszeniu składników wydatków na inne cele) nakładów finansowych lub pozafinansowych, ukierunkowanych na zachowanie lub podwyższenie jakości i wartości kapitału ludzkiego w organizacji, umożliwiającego jej przetrwanie, rozwój oraz zwiększenie atrakcyjności przedsiębiorstwa jako pracodawcy [Lipka 2010, s. 32].

Inwestycje w kapitał ludzki mogą mieć charakter obligatoryjny bądź fakultatywny (przykładem tych ostatnich są programy praca-życie). Jeśli w polityce personalnej przedsiębiorstwa hotelarskiego realizowany jest model sita, to przeważają inwestycje o charakterze obligatoryjnym, a inwestycje fakultatywne nierzadko w ogóle nie występują. Niektóre inwestycje w pracowników są więc obowiązkowe (np. szkolenia BHP), a inne mają charakter fakultatywny (np. dodatkowe szkolenia językowe). 
Uwzględniając składowe kapitału ludzkiego, można wyróżnić inwestycje zorientowane na wiedzę, umiejętności (np. szkolenia), zdrowie (np. dodatkowa opieka medyczna, inwestycje w programy praca-życie i w warunki pracy), motywację, postawy (np. badanie opinii pracowników, zarządzanie partycypacyjne). Niektóre inwestycje w kapitał ludzki realizuje się w krótkim okresie (np. opanowanie umiejętności obsługi komputera dzięki inwestycjom szkoleniowym czy przeprowadzenie jednokrotnego badania opinii pracowników), a przeprowadzenie innych inwestycji (np. kształtowanie zaufania w organizacji) bywa długotrwałe [Lipka 2010, s. 59].

Klasyfikacja inwestycji nie może również pomijać źródeł finansowania. Dysponowanie odpowiednimi środkami stanowi bowiem wyjściowy konieczny warunek wszelkiego inwestowania, choć pewne inwestycje w kapitał ludzki (np. w zaufanie, zarządzanie partycypacyjne, opanowanie konfliktów) wymagają przede wszystkim nakładów niematerialnych. Niektóre inwestycje w pracowników są w całości finansowane przez pracobiorców (tzw. samokształceniowe) bądź pracodawców, inne zaś mają charakter mieszany (np. pracownicy pokrywają część opłat za dodatkowe szkolenia językowe).

\section{Znaczenie inwestycji retencyjnych dla przedsiębiorstw hotelarskich}

Inwestycje retencyjne (tj. inwestycje w lojalność pracowników) zorientowane są na zatrzymanie pracowników w firmie. Główne korzyści dla przedsiębiorstwa hotelarskiego wynikające z lojalności pracowniczej to:

- retencja (stabilność) zatrudnienia,

- wzrost wydajności pracy,

- utrzymanie klientów firmy.

Zaletą lojalności pracowniczej jest fakt, że w wyniku dłuższego pozostawania pracownika w przedsiębiorstwie nabywa on doświadczenia zawodowego. Pracownicy dłużej pracujący w hotelu mają unikalną wiedzę na temat indywidualnych preferencji klientów czy cech produktu, przez co może być świadczona przez nich wyższa jakość obsługi. Lojalność pracowników determinuje także lojalność klientów. Stabilność zatrudnienia jest bardzo ważna w odniesieniu do stanowisk pracy, na których od pracowników wymaga się znajomości indywidualnych potrzeb czy preferencji klientów. Zbyt częste zmiany wśród personelu w przedsiębiorstwach hotelarskich (np. recepcjonistów, kelnerów, kucharzy, masażystów) powodują lukę w obsłudze, której wynikiem jest niezadowolenie klienta, rozbieżność między tym, czego klient się spodziewa, a tym, czego doświadcza [Hill, Alexander 2003].

Inwestycje retencyjne mogą przybierać różne formy, np. inwestycji szkoleniowych, inwestycji w zdrowie, programów praca-życie. Komplementarność inwestycji szkoleniowych i retencyjnych uwarunkowana jest treścią szkoleń. Jak bowiem wynika z badań [Lipka 2010, s. 27], szkolenia dopasowane do specyfiki pracy w firmie zmniejszają chęć odejścia z niej, podczas gdy szkolenia o tematyce ogólnej 
zwiększają ją, o ile pracownicy nie otrzymali awansu. Inwestycje retencyjne obejmują także inwestycje w: zdrowie i sprawność fizyczną, warunki pracy, dodatkową opiekę medyczną, programy praca-życie, zarządzanie partycypacyjne oraz opanowanie konfliktów.

Zaburzenie równowagi między pracą zawodową a życiem osobistym (work-life balance, W-LB) ma negatywne następstwa dla pracowników i ich rodzin, a także nie sprzyja jakości i efektywności pracy. Pracownicy wyczerpani pracą, wypaleni zawodowo stanowią $\mathrm{w}$ dłuższej perspektywie poważny problem dla przedsiębiorstw hotelarskich. Dlatego przejawem inwestowania w kapitał ludzki i zwiększania przewagi konkurencyjnej przedsiębiorstwa są działania z zakresu W-LB. Powinny one obejmować [Grobelna i Tokarz-Kocik 2016]:

- pomoc w sprawowaniu przez pracownika opieki nad dziećmi;

- zapewnianie elastycznych warunków pracy;

- udzielanie okazjonalnych urlopów na prośbę pracownika znajdującego się w specyficznej sytuacji życiowej (dodatkowe urlopy rodzicielskie, naukowe);

- zapewnianie szeroko pojętej pomocy i wsparcia dla personelu z obszarów pozazawodowych, typu: kultura, rekreacja, zdrowie; organizowanie pikników i spotkań integracyjnych dla pracowników oraz ich rodzin.

Podstawą efektywnego działania przedsiębiorstwa hotelarskiego jest integracja jego celów z celami pracownika, co pozwala na postawienie wniosku, iż wszelkie działania ze strony pracodawcy, ułatwiające godzenie życia osobistego i zawodowego personelu, przyczyniają się do wzrostu owej efektywności.

Przejawem inwestycji retencyjnych jest przechodzenie od kształtowania zadowolenia z pracy do kształtowania zaangażowania organizacyjnego. Do jego odnotowania przyczyniły się wyniki badań empirycznych, wskazujące, że nawet zadowoleni z pracy pracownicy mogą z firmy odchodzić. Rzadziej natomiast odejścia dotyczą osób zaangażowanych organizacyjnie, czyli takich, które są przywiązane do swojej firmy i identyfikują się z nią. Ważniejszy dla nich jest ich kontrakt psychologiczny z organizacją aniżeli umowa o pracę [Lipka 2010, s. 68].

$\mathrm{Z}$ porzuceniem działań zmierzających do zadowolenia pracownika na rzecz zaangażowania wiąże się tendencja do zastępowania motywowania instrumentalnego motywowaniem instrumentalno-autotelicznym. Jeśli bowiem pracownicy mają się bardzo zaangażować w pracę, to musi ich łączyć z nią coś więcej niż tylko wynagrodzenie materialne i motywowanie za pomocą zewnętrznego oddziaływania [Grobelna $i$ in. 2016].

Tendencja do przeobrażenia sposobów motywowania łączy się z inwestycjami w zarządzanie partycypacyjne, przeobrażanie kultury organizacyjnej, marketing personalny wewnętrzny, we wzrost różnorodności kapitału ludzkiego organizacji, w zaufanie, w łowienie i rozwój talentów, w opanowanie konfliktów oraz badanie opinii pracobiorców. Zahamowanie procesu inwestowania w pracowników wiąże się z określonymi konsekwencjami dla przedsiębiorstwa hotelarskiego. Przedstawiono je na rysunku 1 . 


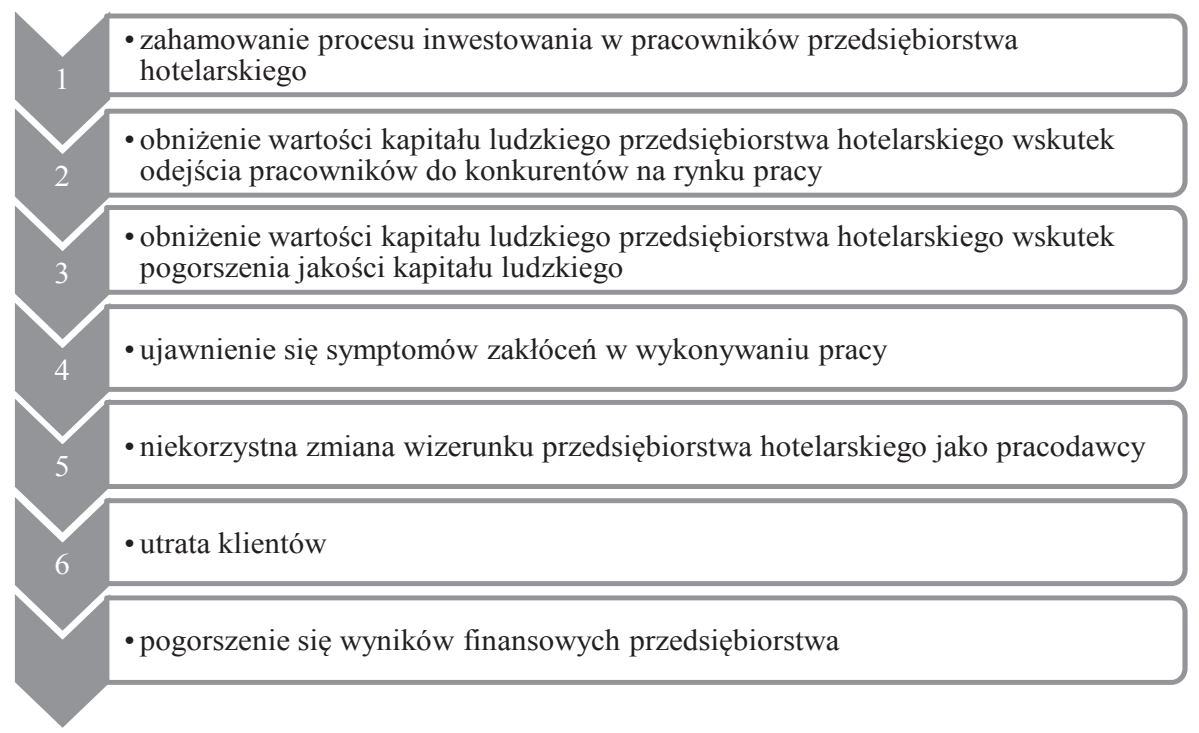

Rys. 1. Ekonomiczne konsekwencje zahamowania procesu inwestowania w kapitał ludzki przedsiębiorstwa hotelarskiego

Źródło: opracowanie własne na podstawie [Lipka 2010, s. 39].

Brak inwestycji retencyjnych wzmaga poziom fluktuacji kadr, a to z kolei wiąże się z koniecznością zatrudnienia nowych pracowników, co oznacza dla przedsiębiorstwa hotelarskiego dodatkowe koszty. Jak wynika z badania Saratoga Human Capital Benchmarking [2015], na przestrzeni czterech lat (2011-2015) wydatki związane z pozyskaniem nowego pracownika wzrosły o 40\% (średni koszt rekrutacji w $2015 \mathrm{r}$. wynosił $2640 \mathrm{zł})$. W przypadku przedsiębiorstw hotelarskich odejście pracownika wiąże się nierzadko z utratą przywiązanych do niego klientów, dlatego inwestycje retencyjne są w tej branży niezwykle ważne [Jung, Yoon 2015, s. 22-26]. W określonych sytuacjach mogą one stanowić środek prewencji odpływu pracowników i spadku zyskowności firmy.

\section{Uwarunkowania inwestycji retencyjnych}

Procesy inwestowania w kapitał ludzki muszą być osadzone w makro- i mikroekonomicznej rzeczywistości. Makroekonomiczne realia wiążą się z uwarunkowaniami egzogenicznymi, mikroekonomiczne zaś z wewnętrznymi. Wśród uwarunkowań egzogenicznych ważną rolę odgrywa koniunktura gospodarcza oraz sytuacja na rynku pracy. Zmiany związanych z nimi okoliczności mogą skłaniać firmy do korygowania swoich planów inwestycyjnych. Jak wynika z badań [Bochniarz, Gugała 2005, 
s. 70], inwestycje w kapitał ludzki są najbardziej wrażliwe na zmiany koniunktury gospodarczej i w razie pogorszenia sytuacji finansowej przedsiębiorstwa ulegają zmianom w stopniu większym niż np. inwestycje w kapitał trwały. Dowodzi to braku wśród kierownictwa świadomości deprecjacji kapitału ludzkiego oraz zrozumienia, iż inwestycje w ten kapitał mogą przynieść wysoki zwrot.

Inwestycja w postaci programu lojalnościowego dla pracowników, aby była trafiona, wymaga przeanalizowania barier wejścia do innych przedsiębiorstw. Łatwość ich pokonania lub ich brak powinny skłaniać do intensyfikacji procesu inwestycyjnego. Trafność inwestycyjną podwyższa również przeanalizowanie cech załogi osiągającej pożądane wyniki pracy. Analiza tego rodzaju cech ułatwia ukierunkowanie inwestycji na ukształtowanie określonej postawy wobec przedsiębiorstwa hotelarskiego i jej skutków w postaci pożądanych zachowań (gdyż samo pozytywne nastawienie wobec organizacji nie wyklucza odejścia z niej do konkurentów na rynku pracy). Cechą taką jest specyficzność bądź uniwersalność kwalifikacji. Należy zatem wskazać tych spośród pracowników kluczowych, którzy dysponują uniwersalnymi kwalifikacjami, ze względu na które inne firmy mogą bez trudu zaoferować im korzystniejsze warunki finansowe [Lipka 2010, s. 152]. Należy przeanalizować lokalny branżowy rynek wynagrodzeń, gdyż ich niski poziom będzie stanowił czynnik odpychający pracowników. Pracownicy mogą akceptować to, że ich firma nie jest rynkowym liderem płacowym, ale pogłębiające się różnice płacowe nierzadko doprowadzają do braku zgody na utratę części zarobków, możliwą do odzyskania po zmianie pracy. Odpowiednie wynagrodzenia służą zatem zmniejszaniu podatności na odwerbowywanie [Shaw, Gupta 2015; Strom 2014].

Przygotowywanie inwestycji retencyjnych obejmuje diagnozę nie tylko uniwersalności kwalifikacji pracowników, lecz także ich innych cech. Lojalności sprzyja np. niechęć do wysiłku poznawczego (porównywania ofert pracy), poczucie podmiotowości, w tym poczucie wpływu na rozwiązania przyjmowane w firmie i poczucie ważności własnej pracy w niej, aprobata środowiska związana z realizacją planów zawodowych w określonej firmie, liczenie na dodatkowe korzyści (płace odroczone) przy pozostaniu w organizacji, poczucie niemożności zmiany pracodawcy czy lęk przed nieznanym. Nielojalności natomiast mogą sprzyjać: wysokie aspiracje płacowe, brak osobistych więzi z innymi pracownikami, otwartość na nowe doświadczenia, negatywna ewaluacja wizerunku obecnego pracodawcy, znaczna akceptacja zmienności w życiu zawodowym i postrzeganie jej jako czynnika rozwoju, wysoka samoocena.

Ze względu na indywidualne różnice w układach motywów lojalności i stopniach ich natężenia można wyróżnić cztery typy lojalności pracowników. Są to [Urban, Siemieniako 2008, s. 87-95]:

1. lojalność świadoma - zatrudniony przejawia zaufanie i przyzwyczajenie (gdyż pracodawca spełnia jego oczekiwania na akceptowalnym poziomie), jednak nie jest zaangażowany w sprawy organizacji; 
2. lojalność zaangażowana - to najgłębsza forma lojalności, w której występuje zaangażowanie pozytywne wraz z zaufaniem i przyzwyczajeniem; pracownik jest pozytywnie zaangażowany i wykazuje zaufanie wskutek zaspokojenia swoich potrzeb ekonomicznych (poziom płacy i perspektywy jej wzrostu) i społecznych (udział w podejmowaniu ważnych dla firmy decyzji);

3. lojalność z rutyny - cechuje się wyłącznie przyzwyczajeniem, to znaczy zaangażowanie jest negatywne, a poziom zaufania niski;

4. lojalność warunkowa - u pracownika występuje zaufanie i zaangażowanie negatywne; pracownik grozi, iż w wypadku nieusunięcia przez firmę problemów wywołujących jego negatywne zaangażowanie odejdzie z pracy.

W wypadku lojalności świadomej działania doskonalące proces inwestycyjny powinny polegać na podtrzymaniu osobistych więzi z pracownikiem poprzez częste komunikowanie się z nim. Oprócz personalizacji relacji celowe jest przydzielenie pracownikowi nowych obowiązków, związanych z wyższą płacą. Występowanie lojalności zaangażowanej natomiast skłaniać powinno do działań określających ścieżki awansu stanowiskowego i płacowego. Chodzi o wzmocnienie dotychczasowej postawy oraz przekształcenie zaangażowania wynikającego z pobudek emocjonalnych $\mathrm{w}$ zaangażowanie oparte na przesłankach racjonalnych, a intencji - w działania.

Zidentyfikowanie lojalności z rutyny wymaga przeprowadzenia rachunku opłacalności przekształcenia obojętności pracownika w lojalność pozytywną. Jeśli wynik tego rachunku przekonuje o opłacalności takich działań, to przybrać one powinny formę podobną jak w przypadku lojalności świadomej. W odniesieniu do ostatniego z wyróżnionych na podstawie wewnętrznych mechanizmów jej ukształtowania typów lojalności pracowników, a mianowicie lojalności warunkowej, nakłady sprowadzają się do porównania kosztów utraty pracownika z kosztami zniwelowania wskazanych przez niego problemów; nakłady na doskonalenie procesów inwestowania w retencję pracobiorców należy skoncentrować na zniwelowaniu czynników determinujących negatywne zaangażowanie pracowników.

Skuteczność procesu inwestowania w lojalność pracowników uwarunkowana jest m.in. jego ciągłością [Lipka i in. 2012]. Nieuwzględnienie dynamiki lojalności w planowaniu rozłożenia tych nakładów grozi zerwaniem przez pracowników więzi $\mathrm{z}$ organizacją.

\section{Zakończenie}

Procesy pracy w hotelarstwie mają odmienny charakter niż w innych branżach gospodarki. Odmienność ta dotyczy wielu aspektów, takich jak choćby całoroczna dostępność świadczonych usług (wiele obiektów hotelarskich ma charakter całoroczny, przez co są do dyspozycji klientów 365 dni w roku, 24 godziny na dobę), charakterystyczna zmianowość (np. 12-godzinne dyżury na stanowisku w recepcji). Cechą charakterystyczną pracy w hotelu jest również jej złożoność, konieczność wykonywania różnych czynności i łączenia funkcji. Ma to szczególne znaczenie w małych 
hotelach, gdzie pewne funkcje muszą być realizowane przez jednego pracownika [Grobelna i in. 2015].

Jednym z podstawowych problemów branży hotelarskiej jest wysoki poziom rotacji kadr. Problem ten po części powodowany jest szybkim rozwojem liczby obiektów hotelarskich i popytem na doświadczonych pracowników. Głównie jednak wynika z ograniczonych inwestycji retencyjnych, tj. mało konkurencyjnych warunków płacowych i zasad motywowania stosowanych przez obiekty hotelarskie. Tworząc systemy motywacyjne w przedsiębiorstwie hotelarskim, uwzględnia się zazwyczaj jedynie pewne ogólne prawidłowości w zachowaniu człowieka, gdy tymczasem konieczne jest analizowanie wielu różnych uwarunkowań związanych z cechami konkretnych osób, na które działają różne motywatory.

Nieprawidłowo dobrane inwestycje retencyjne powodują ryzyko mniejszego zaangażowania pracowników w sprawy przedsiębiorstwa hotelarskiego i związanego z tym obniżenia jakości wykonywanej pracy. Sprzyjać to może powstawaniu dalszych rodzajów ryzyka, m.in. ryzyka niezadowolenia klientów, ryzyka utraty klientów czy ryzyka wzrostu liczby reklamacji. Z wymienionymi rodzajami ryzyka pracodawcy ściśle wiąże się ryzyko utraty wizerunku przedsiębiorstwa hotelarskiego na rynku. Powodować może ono szereg niekorzystnych skutków na płaszczyźnie relacji organizacji z interesariuszami zewnętrznymi (m.in. klientami, kontrahentami czy potencjalnymi pracobiorcami), a w efekcie negatywnie wpływać na pozycję konkurencyjną przedsiębiorstwa na rynku.

\section{Literatura}

Becker G.S., 1962, Investment in human capital: A theoretical analysis, Journal of political economy, no. 70 (5, part 2), s. 9-49.

Bochniarz P., Gugała K., 2005, Budowanie i pomiar kapitału ludzkiego w firmie, Poltext, Warszawa.

Grobelna A., Sidorkiewicz M., Tokarz-Kocik A., 2015, Wybrane determinanty satysfakcji z pracy i efektywności pracowników w branży hotelarskiej, Folia Turistica, nr 35, s. 25-45.

Grobelna A., Sidorkiewicz M, Tokarz-Kocik A., 2016, Job satisfaction among hotel employees: analyzing selected antecedents and job outcomes. Case study of hotels from northern Poland, Argumenta Oeconomica, no. 2 (37), s. 281-310.

Grobelna A., Tokarz-Kocik A., 2016, Work-life balance and its importance for the work process in hospitality industry. a perspective of generation Y employees, Economic and Social Development, Split, s. 489-497, http://www.esd-conference.com/?page=past-conferences (14.02.2017).

Hill N., Alexander J., 2003, Pomiar satysfakcji i lojalności klientów, Oficyna Ekonomiczna, Kraków.

Jajuga K., Jajuga T., 2000, Inwestycje. Instrumenty finansowe. Ryzyko finansowe. Inżynieria finansowa, Wydawnictwo Naukowe PWN, Warszawa.

Jung H.S., Yoon H.H., 2015, Understanding pay satisfaction: The impacts of pay satisfaction on employees' job engagement and withdrawal in deluxe hotel, International Journal of Hospitality Management, no. 48 , s. $22-26$.

Król H., 2006, Kapitał ludzki w organizacji, [w:] Król H., Ludwiczyński A. (red.), Zarzadzanie zasobami ludzkimi. Tworzenie kapitalu ludzkiego organizacji, Wydawnictwo Naukowe PWN, Warszawa. 
Lipka A., 2010, Inwestycje w kapitat ludzki organizacji w okresie koniunktury i dekoniunktury, Oficyna a Wolters Kluwer business, Warszawa.

Lipka A., Winnicka-Wejs A., Acedański J., 2012, Lojalność pracownicza. Od diagnozy typów lojalności pracowników do zarządzania relacjami z pracownikami, Difin, Warszawa

Saratoga Human Capital Benchmarking, 2015, https://www.pwc.pl/pl/zarzadzanie-kapitalem-ludzkim/ assets/pwc-saratoga-hc-benchmarking-2015.pdf (14. 02.2017).

Shaw J.D., Gupta N., 2015, Let the evidence speak again! Financial incentives are more effective than we thought, Human Resource Management Journal, no. 25, s. 281-293.

Strom D.L., Sears K.L., Kelly K.M., 2014, Work Engagement: The Roles of Organizational Justice and Leadership Style in Predicting Engagement Among Employees, Journal of Leadership \& Organizational Studies, no. 21, s. 71-82.

Urban W., Siemieniako D., 2008, Lojalność klientów. Modele, motywacja i pomiar, Wydawnictwo Naukowe PWN, Warszawa. 